
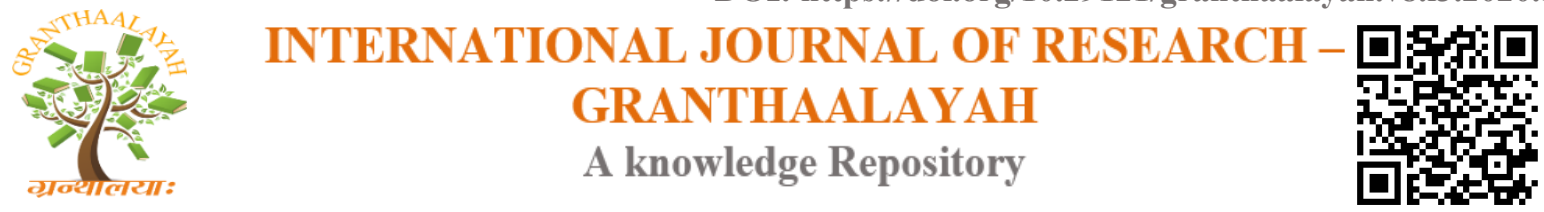

Science

\title{
A RELOOK AT THE DEFINITION OF A METEORITE
}

\author{
Y. V. Subba Rao *1 \\ ${ }^{* 1}$ University Science and Instrumentation Centre, S. V. University, Tirupati, AP, India
}

\begin{abstract}
In Astronomy, a meteorite is a sand- to boulder-sized particle of debris which collides with the earth in the Solar System. Astrobiology Division of NASA asserts that Meteorites are carriers of life building blocks of DNA from space to the earth. Vedic Paradigm and Bhagavad-Gita define that Meteorites are the forms of those persons who fall to be reborn after having enjoyed the fruits of their meritorious deeds in Heaven. Thus, a meteorite appears to be a cosmic and divine dispensation. It is therefore aimed at correlating all these different aspects relating to meteorites and this necessitates a relook at the definition of meteorites for brevity. In this paper, the different aspects pertaining to meteorites are discussed and verified to arrive at a new definition for a 'Meteorite'. Thus, a 'Meteorite is a rock from space with DNA molecules enveloped by the imperishable soul of meritorious persons returned from heaven to Earth to be reborn and collides with the Earth in our Solar System and survives the impact with its composition remaining intact after collision'.
\end{abstract}

Keywords: Astronomy; Astrobiology; Vedic Paradigm; Bhagavad Gita; Meteorites; DNA.

Cite This Article: Y. V. Subba Rao. (2020). "A RELOOK AT THE DEFINITION OF A METEORITE." International Journal of Research - Granthaalayah, 8(3), 80-85. https://doi.org/10.29121/granthaalayah.v8.i3.2020.131.

\section{Introduction}

This paper is about creating a single definition of meteorites incorporating all the recent results of scientific research carried out by different space research organizations, besides the ageless unconventional Hindu concept about them. Nonetheless the ageless unconventional Hindu concept of meteorites corresponds to those of modern scientific research findings.

This paper is a mix of all the scientific findings and the Hindu concept in arriving at a single definition of a meteorite uplifting its status from a lifeless rock into one with full of life building blocks and origin of source of life on this earth. This paper is prepared with the aim and objective to redefine a meteorite relating the human with the cosmos. 


\section{Definition of Meteorite in Different Disciplines}

Meteorite is defined in various disciplines based on the composition and the purpose it serves. Thus:

\subsection{Meteorite in Astronomy and Geology}

A meteoroid is a sand- to boulder-sized particle of debris in the Solar System which collides with the Earth. The visible path of a meteoroid that enters Earth's (or another body's) atmosphere is called a meteor, or colloquially a shooting star or falling star [1]. If a meteoroid reaches the ground and survives impact, then it is called a meteorite [2]. Many meteors appearing seconds or minutes apart are called a meteor shower. The root word 'meteor' comes from the Greek meteōros, meaning "high in the air" [3]. A meteorite is a solid piece of debris from an object, such as a comet, asteroid, or meteoroid, that originated in outer space and survived its passage through the atmosphere to reach the surface of a planet or moon. ... For geologists, a bolide is a meteorite large enough to create an impact crater. Therefore, a 'Meteorite' is a rock in the Solar System which collides with Earth and survives impact. (Figure 1.).

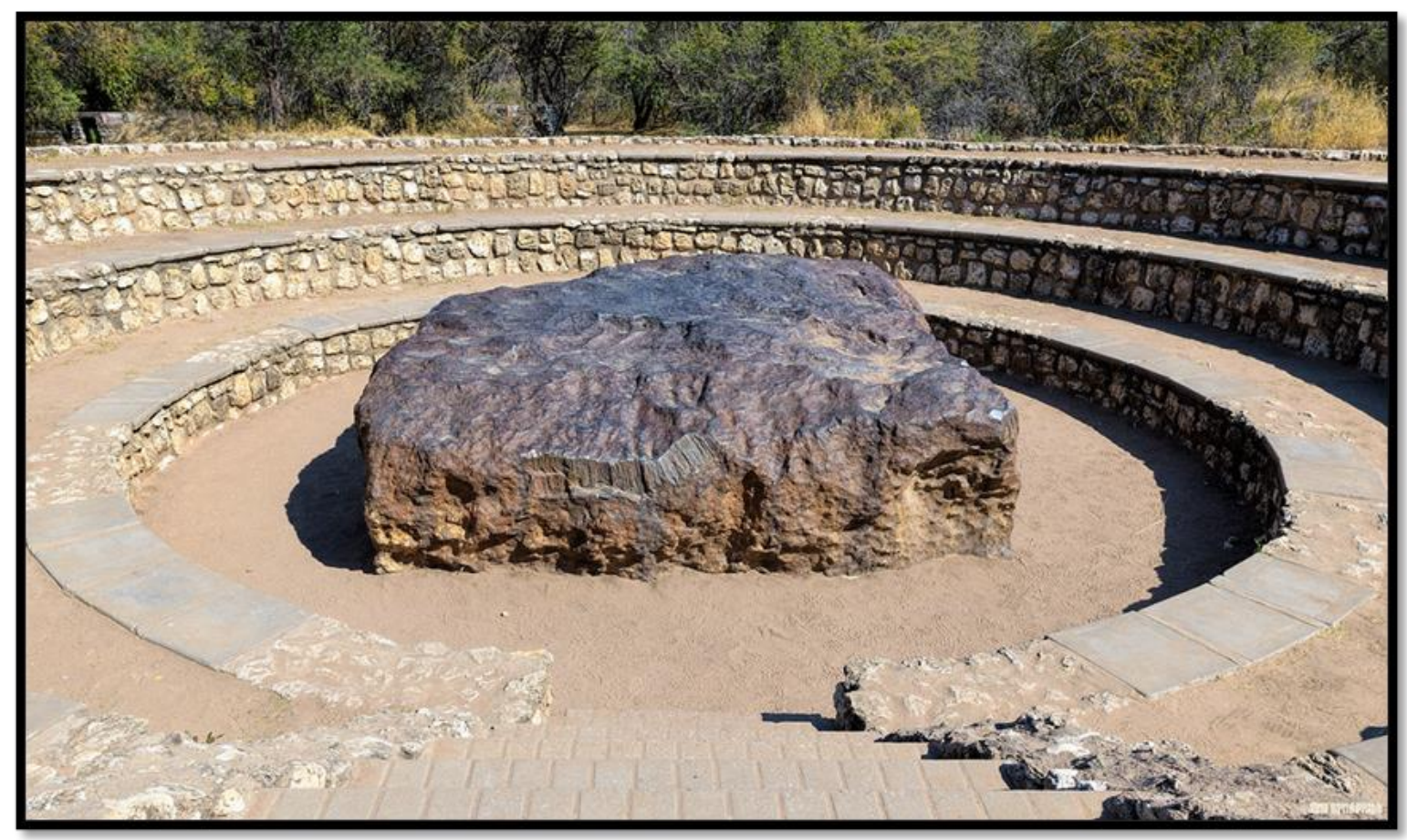

Figure 1: World's Largest Meteorite, Hobba Meteorite

\subsection{Meteorite in Astrobiology}

Scientists of Astrobiology Division of NASA have discovered evidence supporting the theory that part of our DNA was created in space. It was established that meteorites contain amino acids, which are the building blocks of the body's proteins, but now we know that meteorites also contain DNA and RNA, the building blocks of the body's genetic material. 
NASA-funded researchers have evidence that some building blocks of DNA, the molecule that carries the genetic instructions for life, found in meteorites were likely created in space and available as readymade kits. The research gives support to the theory that a "kit" of ready-made parts created in space and delivered to Earth by meteorite and comet impacts assisted the origin of life [4]. 'Meteorite' is thus a carrier of DNA Molecules from space to Earth (Figure 2.).

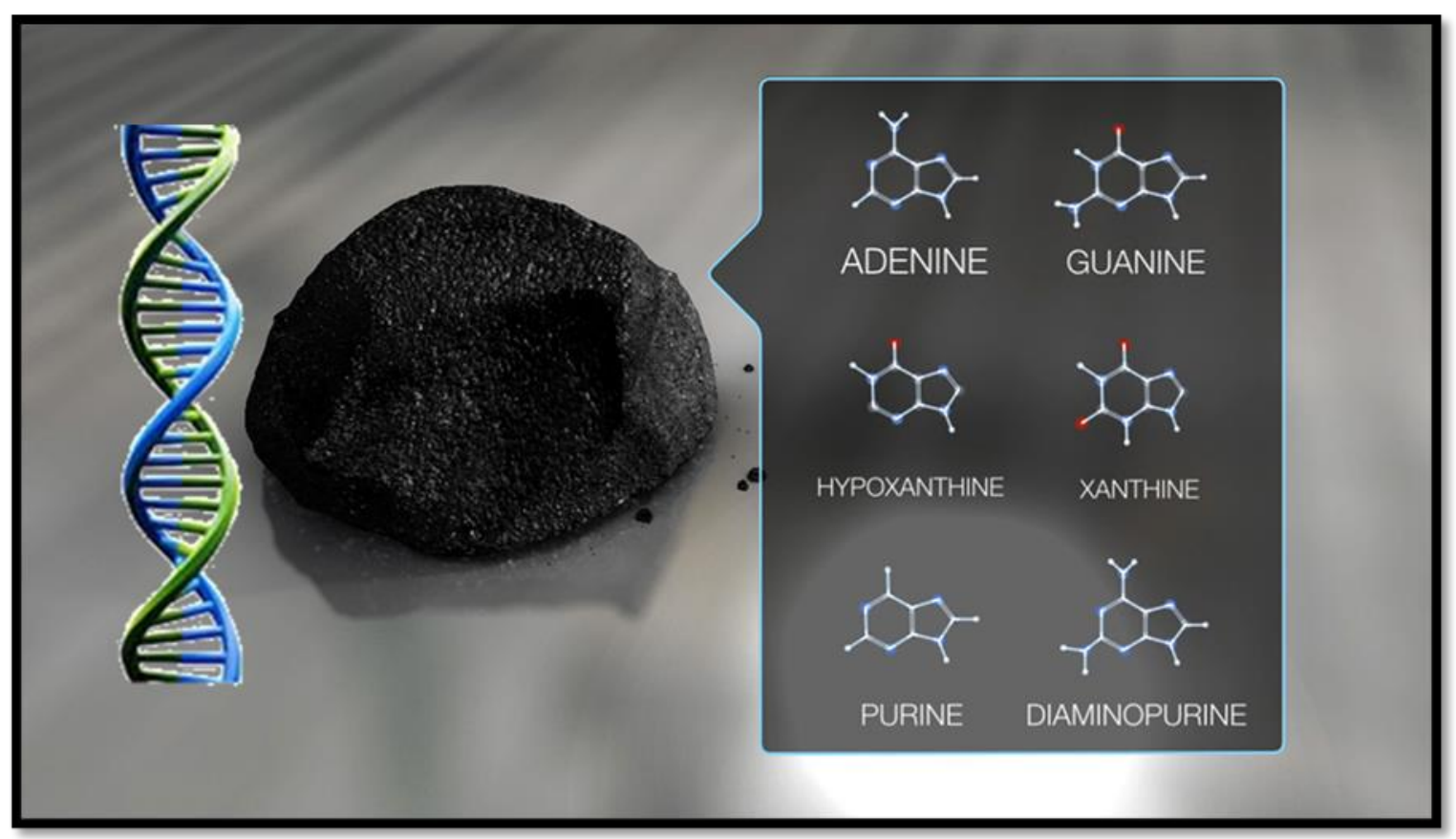

Figure 2: Meteorite containing DNA and RNA, the building blocks of the body's genetic material" (Courtesy: NASA)

\section{Hindu Concept of Meteorites: Brihat Samhita and Bhagavad Gita}

Varāhamihira, Indian Astrologer and Astronomer par excellence of the 5th century, in one of his works, "Brihat Samhita" states that the meteorites are nothing but the forms of those who fall to be reborn after having enjoyed the fruits of their meritorious deeds in Heaven. They are divided into five categories viz. Ignescent Balls, Meteors, Thunder-bolts, Lightning and Shooting Stars (Comets) [5].

Bhagwān Uvacha:

\section{ते तं भुक्त्वा स्वर्गलोकं विशालं क्षीणे पुण्ये मर्त्यलोकं विशन्ति । एवं त्रयीधर्ममनुप्रपनना गतागतं कामकामा लभन्ते ॥९.२१॥}

te tam bhuktvã svarga-lokam visãlam; ksine punye martya-lokam visanti I evam trayi-dharmam anuprapannã; gatãgatam kãma-kãma labhante ॥

Translation: When they have thus enjoyed heavenly sense pleasure, they return to this mortal planet again. Thus, through the Vedic principles, they achieve only flickering happiness.

--- Bhagavad Gita: Chapter 9, Text 21[6] 


\title{
3.1. DNA Molecules in Meteorites Remained Intact
}

"Our research shows that the building blocks of life could, indeed, have remained intact despite the tremendous shock wave and other violent conditions in a comet impact," Blank said. "Comets really would have been the ideal packages for delivering ingredients for the chemical evolution thought to have resulted in life". The amino acids did not break down due to the heat and shock of the simulated crash. Indeed, they began forming the so-called "peptide bonds" that link amino acids together into proteins. The pressure from the impact of the crash apparently offset the intense heat and supplied the energy needed to create the peptides, she explained. In other experiments, Blank's team used sophisticated computer models to simulate conditions as comets collided with Earth. Blank suggested that there may well have been multiple deliveries of seedlings of life through the years from comets, asteroids and meteorites. Therefore, in a Meteorite the building blocks of life remained intact despite the tremendous shock wave and other violent conditions after collision [7]. Earth received heavy and continuous meteorite bombardment for about 700 million years from 4.5 to 3.8 billion years. The whole process is indeed a cosmic dispensation. Meteorites cloak a chemical signature almost as old as the solar system [8].

\subsection{DNA Molecules in Meteorites Remain Intact: Bhagavad Gita}

Bhagwān Uvacha:

\author{
नैनं छिन्दन्ति शस्त्राणि नैनं दहति पावक:| \\ न चैन क्लेदयन्त्यापो न शोषयति मारुत: || 23\| \\ --- vide the Bhagavad Gita: Chapter 2, Text 23[9]
}

Translation: Weapons cannot shred the soul, nor can fire burn it. Water cannot wet it, nor can the wind dry it.

Consciousness, which is the symptom of the soul, can be perceived by material instruments, but the soul itself cannot be contacted by any material object. This is so only because the soul is divine, and hence beyond the interactions of material objects. Shree Krishna expresses this vividly by saying that wind cannot wither the soul, nor can water moisten it or fire burn it.

The amino acids did not break down due to heat and shock of the simulated crash is possibly due to the invisible and indestructible shield called spirit or Soul enveloping them. It is a dogma that only what can be tested in labs and proved by material evidence is real. All the rest is illusion or delusion. Science gives us knowledge, but knowledge alone is not enough for man. He is also in dire need of wisdom and spiritual discernment for the survival of humanity.

\section{Results}

- A 'Meteorite' is a rock in the Solar System which collides with Earth and survives impact, defines Astronomy.

- A 'Meteorite' is a carrier of DNA Molecules from space to Earth according to NASA findings.

- Therefore, in a Meteorite the building blocks of life remained intact despite the tremendous shock wave and other violent conditions after collision. 
- Hindu concept holds that Meteorites are the forms of those people who have done meritorious deeds on earth go to heaven in astral form with the souls and return to earth only to be reborn.

\section{Discussion}

A 'Meteorite' is a rock in the Solar System which collides with Earth and survives impact after collision. It has been established that some building blocks of DNA (Adenine and Guanine), the molecule that carries the genetic instructions for life, found in meteorites were likely created in space [10]. Therefore a 'Meteorite' is a carrier of DNA Molecules from space to Earth. Hindu Concept of Meteorites is nothing but the forms of those who fall to be reborn after having enjoyed the fruits of their meritorious deeds in Heaven and that the soul can never be cut into pieces by any weapon, nor can he be burnt by fire, nor moistened by water, nor withered by the wind. Research shows that the building blocks of life could, indeed, have remained intact despite the tremendous shock wave and other violent conditions after collision in a meteorite impact (NASA). This cannot happen unless these molecules are protected from destruction by being enveloped by the soul which is not only permanent but also indestructible by any natural elements or by artificial destructible weapons.

Further, this natural "interplanetary transportation system" begs a fascinating question: If primitive and nearly indestructible micro-organisms exist on a given planet, must they by definition as a natural act of nature, travel to their immediate solar-system neighbors? [11]. Of course, and plausibly, the DNA molecules contained in the Meteorites might have been the molecules of those meritorious persons deceased initially and transported to heaven in their astral form and returned to earth from Heaven to be reborn.

From the discussion based on the foregoing facts, and summing up all the data related to the Meteorites, a Meteorite can be defined thus:

\section{Conclusion: New Definition of a Meteorite}

A "Meteorite is a rock from space, carrying with it DNA molecules covered by the soul of meritorious persons returned from heaven to Earth to be reborn, which collides with the Earth in our Solar System and survives the impact with its composition remaining intact after collision with the Earth".

\section{Acknowledgements}

I thank all my friends and members of my family who have encouraged me to write a paper giving the new definition to a 'Meteorite'.

\section{References}

[1] https://www.sciencedaily.com/terms/meteor.htm)

[2] www.space-exploratorium.com/meteors.htm) 
[3] https://www.lifehacker.com.au/2017/08/whats-the-difference-between-a-meteor-comet-andasteroid/

[4] Callahan (Aug 9, 2011). DNA Blocks found in Meteorites. Proceedings of the National Academy.

[5] Ramakrishna Bhat M. (2010). Varahamihira's Brihat Samhita, volume 1, Chapter 33. Signs of Meteors, pp307. Motilal Banarsidas Publishers Pvt. Ltd. Delhi. ISBN 9788120810600

[6] Bhagavad-Gita Large-Print Edition. (2003). page 11 Chapter 9 Text 21. The Devanagari text.www.sanskritweb.net/sansdocs/gita-big.pdf

[7] cosmosmagazine.com > biology, Did our DNA arrive from space? | Cosmos - Cosmos Magazine Cosmos 62 - Apr-May 2015

[8] https://sgforums.com/forums/1381/topics/446087/2/Mars meteorites cloak a chemical signature almost as old as the solar system. (Jul 25, 2013). www.dailygalaxy.com

[9] Bhagavad-Gita Large-Print Edition. (2003). page 11 Chapter 2 Text 23. The Devanagari text.www.sanskritweb.net/sansdocs/gita-big.pdf

[10] https://www.telegraph.co.uk/news/science/space/9169518/Life-brought-to-Earth-by-comets.html

[11] http://atheistuniverse.net/group/thedailycosmos/forum/topics/super-earths-could-they-seedmicrobial-life-in-their-solar-system

\footnotetext{
*Corresponding author.

E-mail address: yvsubbarao2004@y ahoo.com
} 